Meta

Journal des traducteurs

Translators' Journal

\title{
Interdisciplinarity Education as an Instrument of Training Terminologists in the Fields of Medical Genetics and Genetic Diseases
}

\section{Vladimir N. Nekrassoff}

Volume 31, numéro 1, mars 1986

Traduction et terminologie médicale

Medical Translation and Terminology

URI : https://id.erudit.org/iderudit/003719ar

DOI : https://doi.org/10.7202/003719ar

Aller au sommaire du numéro

Éditeur(s)

Les Presses de l'Université de Montréal

ISSN

0026-0452 (imprimé)

1492-1421 (numérique)

Découvrir la revue

Citer ce document

Nekrassoff, V. N. (1986). Interdisciplinarity Education as an Instrument of

Training Terminologists in the Fields of Medical Genetics and Genetic Diseases.

Meta, 31(1), 85-97. https://doi.org/10.7202/003719ar d'utilisation que vous pouvez consulter en ligne. 


\title{
INTERDISCIPLINARY EDUCATION AS AN INSTRUMENT OF TRAINING TERMINOLOGISTS IN THE FIELDS OF MEDICAL GENETICS AND GENETIC DISEASES
}

\author{
VLADIMIR N. NEKRASSOFF
}

\begin{abstract}
For close to two centuries, medical genetics and genetic diseases have been of great interest to physicians the world over, and several hundred syndromes - each one with its own symptoms and signs and special terminology - have been described in literature. Today genetics can predict disease by indicating patients at risk, and genetic engineering, i.e. genetic manipulations by which an individual having a new combination of inheritable properties is established, is making great advances to the benefit of genetically tainted individuals. No doubt, there will be major demands in the near future for translators knowledgeable in genetics, and they will have to face their task without access to reliable dictionaries or glossaries.

The dilemma of the absent terminologies represents a rationale for interdisciplinary studies - a great problem in itself. Many academic educators and administrators have ambivalent attitudes toward interdisciplinary educational efforts. My rationale for interdisciplinary studies in the field of multilingual terminology is based on the common observation that problems in our - real - world are not separable into disciplines. A corollary of this view, at the graduate level, is that instruction requires concomitant research that is related to fundamental problems of their own and aware of the way in which new knowledge can contribute to the solution of important social problems - in the present case the treatment and prevention of heritable diseases.

Despite the reasonableness of these arguments, educational efforts along interdisciplinary lines confront major difficulties in virtually every area related to the process of education. These problems involve philosophy, faculty, students, curriculum, research, money and evaluation. Graduate students with interests and high competence in a variety of fields relevant to the resolution of terminological problems - here, applied linguistics and medical genetics - are essential in achieving the intellectual crossfertilization expected of a successful interdisciplinary program. The universities, traditionally a source of trained people, will probably try very hard to establish proper programs. However, they are in relatively poor shape to do so. In most schools, equipment for training and research is antiquated, and government funds for support of research and teaching have diminished. But in order to maintain viable communication in various languages in this field of medical science and, thus, to assist medical progress, we absolutely need personnel properly trained in problem-oriented programs. The present surge in interest in solving genetic problems then renews the demand for new or different programs for graduate students of translation and terminology courses. The need for a continuing flow of well-trained terminologists is obvious, and that need warrants continued multidisciplinary efforts despite the educational problems mentioned above.
\end{abstract}


The appropriate level for such programs may be the masters, the doctorate, or successive two-degree programs. The job market probably determines the level of education at which such an interdisciplinary program is likely to be successful.

For the purpose of this paper, a medical terminologists is the experienced translator who has special knowledge in the field of medicine in general and in a specific subfield - here, in medical genetics and genetic diseases - in particular. It is obvious to me that a terminologist trained as generalist will encounter great difficulties in establishing medical terminology in two languages simply because medicine to a large extent is an art, and not a precise science like mathematics or physics, where it is relatively easy to establish equivalent terms in two languages.

All researching terminologists are drowned in a flood of scientific publications, journals, conference proceedings, handbooks, and so on ad infinitum. Even if we should succeed in doubling or tripling our reading speed, we still will not be able to cope with the bulk of information confronting us. However, I believe that we can predict that reading still will be of main importance in terminology work for many years to come.

German (G.)-English (E.) translators have available several excellent dictionaries, which are truly indispensable. However, all of them have been marketed by German and Swiss publishers. The attitude of working translators and terminologists towards dictionaries should be friendly, but strongly critical - a realization that arises once the translator has been working for about fifteen years or so. It is not that these dictionaries contain large numbers of errors, but frequently the English equivalents given do not correspond to the terms actually used by our physicians. Two examples may illustrate my point. In Lejeune-Bunjes, Hornhauttrübung (a condition encountered in many genetic diseases) is presented as follows : Hornhauttrübung $f$ (leichte) nubecula (e) / (gitterige) Dimmer's keratitis / (gürtelförmige) Caspar's ring opacity (ae) / (weisse) leucoma (ou). However, the proper equivalents used by our physicians, viz. corneal clouding, corneal opacity, cloudy cornea (as finding), corneal opacification, cloudy infiltration of the cornea (both as process), and, also, corneal dystrophy with opacities, are not listed. A further problem is that neither Caspar's ring opacity nor nebecula [nebula ?] can be found in my three unilingual E. medical dictionaries. Leichte $H$., given as nebecula [?] is "faint grayish or foglike opacity of the cornea," or "hazy cornea" (as finding). And the second example : Oberflächensensibilität is given in all my G.-E. medical dictionaries as "superficial sensitivity." The problem here is that that term is not listed in my E. medical dictionaries, and I myself have never heard it as physician (including a residency at the Montreal Neurological Institute) or seen it in E. medical literature. The proper $\mathrm{E}$. medical terms are : tactile sensibility, capability of perceiving tactile stimuli, consciousness of tactile sensation, appreciation of slight contact with the skin (or mucous membrane). Correspondingly, Oberflächenschmerz is "pain perceived in the skin."

These two examples demonstrate that the medical terminologist in his compilation must be well acquainted with usages in both languages. The suspicion all too often arises that terminologists in the original language coin their own terms in the other (target) language without taking the trouble of researching sources in the target language - a most unacceptable approach!

The well-trained terminologist then must be able to handle both his languages clearly, explicitly, and economically even when he is confronted with jargon, errors of meaning, silly expressions, sesquipedalian terms, awkward and invented usages, and unnecessary neologisms. Errors in terminology have a way of becoming established by a kind of law of mass action. If something is said or written often enough, regardless of whether it is wrong to start with, it becomes accepted. Please note! 
Within the framework of this review of some basic principles of terminology creation and discussion of some key problems of medical terminology in two languages, viz. German and English, I have not been able to give an overall picture of the whole scene of medical terminology, but intended to present some points of view which might motivate readers - and translators and terminologists in particular - to devote themselves to studying this important field in medical communication more intensively. In our approach to establish proper terminological equivalents we must first stress the semantic aspects and treat the concepts of discipline and responsibility of communication involving two or more languages. These are two sides of the same coin : discipline because it is necessary to adhere to rules to minimize ambiguity, and responsibility because it needs to be established who is responsible for assuring ultimate understanding - the author or: the translator - or both.

I do not hesitate to say that medical terminologists and translators play a vital role in the prompt and accurate dissemination of medical knowledge. The effectiveness of the physician treating, or trying to prevent, genetic diseases is in direct proportion to his clinical judgement, i.e. his ability to understand pertinent data available in literature in various languages. Our efforts in the end serve the physician and, thus, his patient. That makes medical translating a truly rewarding profession.

\section{MEDICAL GENETICS AND GENETIC DISEASES : A GERMAN-ENGLISH GLOSSARY}

Abänderungsspielraum

Abbauenzymblock

Abfolge von Entwicklungsschritten

Absterben, normales

Abknickung der Hand

Adduktionsfähigkeit des Auges, verminderte bzw. völlig fehlende

Androgenresistenz der Zielorgane

androtrop

Androtropie

anfärben - sich kräftig a. lassen (Chromosome)

An-sich-Hochklettern

Atmungsunregelmässigkeiten, zerebrale

Atonie der Gliedmassen

Auftreibung, wurstförmige, der Arme und Beine

Augen, auseinanderliegende range of variation

coenzyme inhibition ; coenzyme insufficiency, or coenzyme deficiency (in congenital disorders of metabolism)

sequential developmental steps

death by normal attrition; normal attrition; death due to nongenetic causes; nongenetic death

inferior radioulnar subluxation (due to a curvature of the lower extremity of the radius, in Madelung's deformity); clubhand with deviation to the ulnar side

partial or complete absence of adduction of the eye

inability of the end organs to respond to (normal circulating levels of testosterone (in GoldbergMaxwell-Morris syndrome)

prevalent in male ; in males only ; predominant in men; limited to male; or affecting males more frequently than females (hereditary disease)

androtropism; predominance in men; preponderance in males; prevalence in male

stain heavily (chromosome or chromosome segments)

Gowers' maneuver to arise when squatting on the floor (the need of a patient distrophy - when squatting, to have to place his hands on his thighs and to thrust his body upward to achieve the erect position)

irregular gaspy breathing (in maple syrup syndrome)

muscular atonia of the limbs

arms and legs appear cylindrical (in Brugsch's syndrome)

wide-set eyes; widely spaced eyes; hypertelorism 
Augen, hautüberwachsene

Augenabstand, grosser

Augenfurche( $n$ )
Augenmissbildung

Aurikularanhänge

Ausbauchung des Kammerseptums ausmerzen

austernartig (Eierstock)

auswirken, sich - sich positiv bzw. negativ a. sich sowohl positiv als auch negativ a,

Ballenhohlfuss

Bambushaar

Bänderschlaffheit

Bauchdeckenaplasie (-Syndrom)

Beckenhorn (-hörner)

Begleitmissbildungen

Belastungschance

Beweglichkeitsdefekt

B. des Auges

Bewegungen, puppenartige

Blasenhirn

Blasenlunge

Blutdruckunterschied zwischen Armen und Beinen (bzw. oberer und unterer Körperhälfte) cryptophthalmia ; hidden eye (skin passing continously from forehead onto cheek over a rudimentary eye); total enophthalmia

wide-set eyes; ocular hypertelorism ; extreme width between the eyes (widened bridge of the nose resulting in increased distance between the eyes)

optic groove(s) (22-day human embryo)

ocular anomaly ; ocular defect ; eye defect ; (congenital) anomaly of the eye(s) (like spherophakia in Alport's syndrome)

pre-auricula appendages; auricular appendices (in Goldenhar's syndrome)

bulging of septum (into the right ventricle) eliminate (deficiencies); cull ; wash out (mutant alleles from a population); select against

oyster-like (ovary, i.e. the large, pale polycystic ovary with thickened capsules and numerous small follicular cysts beneath the capsule typical for Stein-Leventhal syndrome)

be advantageous or disadyantageous (genes); have advantageous or disadvantageous action (a gene, on the organism) be ambivalent; be both advantageous and disadvantageous (a gene, for the organism)

pes equinoexcavatus; talipes equinoexcavatus ; $t$. equinus and $t$. excavatus combined ; $t$. equinovacus

bamboo hair ; trichorrhexis invaginata swellings of the hair shaft, resembling joints of bamboo, in Netherton's disease)

lax ligaments (in hyperlysinemia); loose ligaments (leading to increased extensibility of the joints); hyperextensibility of ligaments

prune belly syndrome; (congenital) abdominal muscle deficiency (syndrome); (partial or complete) absence of abdominal muscles (in [F.] Fröhlich's syndrome, Orbinsky's syndr., EagleBarrett's s.)

iliac horn(s) (symmetrical bilateral central posterior iliac processes, in nail-patella syndrome and arthro-onychodysplasia) associated abnormalities; associated deformities risk figure (in a genetic situation)

motor defect

oculomotor defect

jerky puppet-like movement; ataxic jerky movement (in Angelman's happy puppet syndrome); ataxic jerky movements resembling those of puppet

hydroencephaly; internal hydrocephalus; Whytt's disease

bubbly lung (in Wilson-Mikity syndrome)

decrease of blood pressure on the arm with (tendency to) hypertension on the legs (in Takayasu's syndrome) 
Blutungsneigung

Bogenmuster

Bratwurstfinger

Bruchneigung

Brust - eine weibliche B. haben

Buckelbildung im Fontanellenbereich

Biürstenschädel (Röntgenbild)

Cherubi(ni)smus

Chromatinnetzwerk, fädiges

chromosomenbürtig

Clowngesicht

Dammpterygium

Dellenbildung bei Beklopfen

Dentinmissbildung

Determinierungsfaktor

Dollarhaut

Doppelmissbildung

Dreschflegelfuss

Durchschlagskraft

durchstreckbar

Dyzenzymie

Eiigkeitzdiagnoses (bei Zwillingen)

Einfliusse, nichtgenetische

Einmündung, anomale, der rechten Lungenvenen in die untere

Hohlvene easy bruising ; excessive bleeding ; bruising from trivial injuries; bleeding tendency ; tendency to hemorrhage ; bleeding associated with minor trauma or surgery; spontaneous hemorrhages (as sign); spontaneous appearance of ecchymoses; easy development of petechiae ; easy bruisibility ; tendency to bruise ; susceptibility to bruising

arch pattern (in dermatoglyphics)

finger(s) with soft tissue hyperplasia ; finger's with hyperplastic subcutaneous tissues

predisposition to fracture (in Albers-Schönberg's syndrome)

have female breast development; (also : have a female body contour)

bulging in region of (anterior) fontanel ; bossing in region of (anterior) fontanel; head pointed in region of anterior fontanel ; prominent frontal area ; frontal bone bossing

hair-on-end appearance of the skull (X-ray); marked thickening of diploe of skull with perpendicular striations between thinned inner and outer tables (in Cooley's syndrome)

cherubism ; Jone's disease ; familial fibrous dysplasia of the bones syndrome; familial fibrous dysplasia of the jaws; familial cystic disease of the jaws

lacy network of chromatin

chromosomally borne (determinants)

clown-like face or facies, i.e. the facies typical for (Cornelia) de Lange's syndrome, with synophrys, long curly eyelashes, hypertelorims with antimongoloid palpebral fissue, and small nose with inverted nostrils

perineal webbing; perineal pterygium

palpation reveals doughy consistence (of calves etc., in muscular dystrophy)

imperfect dentinogenesis ; imperfect dentinification determinant (n.)

telangiectatic skin typical for defective functional activity of the liver cells

monstrum duplex, m. duplicitas; double monsters ; conjoined malformed twins

dropfoot ; foot drop with simultaneous lesions of the femoral and hip muscles

penetrance (of a gene)

extendable (knee)

enzymic dysfunction; disturbance of the secretion and/or interaction of enzymes

diagnosis based on test of similarity

(environmental) influence of a nongenetic nature anomalous yenous drainage of the right lung to inferior vena cava; anomalous venous drainage through abnormal pulmonary vein of the right lung that joins the inferior vena cava (= scimitar syndrome) 
Einschlagen, reflektorisches, des Daumes bei passiver Streckung der 2. bis 5. Finger

Einschränkung der Handgelenk- bewegung E. der Öffnugsfähigkeit des Mundes

\section{Eintrefferkinetik}

einwärtsgekehrte Füsse

Elevationshemmung des Armes über $90^{\circ}$ hinaus

\section{Endorganresistenz gegen Parathormon}

Engelflügelstellung

Entartung

E., maligne

m. E. dieser Krankheit ist möglich

E., Neigung zur malignen

Entartungsreaktion

Entengang

Entgleisung (Stoffwechsel-)

Enthirnungsstarre

E. - Verblödung mit schliesslicher $E$. entspiralisiert

Entwicklungshemmung

Entwicklungsstillstand

Entwicklungsverlauf, normaler (eines Kindes) Entwicklungsverzögerung

Enzymdefekt, erblicher passive extension of second to fifth fingers (affected to some degree by flexion contracture) result in involuntary flexion, opposition and adduction of the thumb of that side

limited wrist motion

limitation of mouth movements; difficulty in opening the mouth

single hit kinetics (of mutagenesis)

inversion of feet ; inverted feet (in HallervordenSpatz syndrome)

the arm cannot be raised above the right angle; abduction of shoulder beyond $90^{\circ}$ is impossible (in Sprengel's deformity) Emporschnellen (des ptotischen Lids) rapid elevation (of ptotic upper lid when opening mouth, in Gunn's syndrome) refractoriness of end organ response to

parathyroid hormone; diminished end-organ responsiveness to parathyroid hormone (Seabright-Bantam syndrome) (i.e. administration of parathyroid hormone or extract does not produce significant changes in the clinical picture of this syndrome)

scapula alata ; winged scapula degeneration; dystropy (of the cornea) malignant degeneration; $m$. transformation (of tissues)

this disease is considered to be a precancerous condition

tendency to undergo malignant changes

reaction of degeneration; absence of response to both galvanic and faradic stimulus in a degenerated nerve, and to faradic stimulus in the muscles supplied by it

wide-based gait ; waddling gait

(metabolic) derangement

decerebrate rigidity; exaggerated postural tone in the antigravity muscles; rigid contraction of the antigravity muscles; decerebrate posture (finding); spasticity and decerebrate posturing of the limbs (finding);

mental retardation progressing to decerebration untwisted ; extended (chromosome) ; decoiled ; uncolied ; unrolled ; unwound (strands) ; stretched out

delayed development ; arrested d. ; slow d. (in an infant)

arrest of development (mental and/or physical); failure to develop; $f$. to thrive ; runting (as symptom in Di George's syndrome)

normal reaching of early milestones

physical and mental retardation; lag of development ; developmental retardation ; retardation of normal development ; development appears retarded (finding) inborn error of enzyme metabolism 
Equinovarusstellung der Füisse

erbbedingt

e. - rezessiv e. sein

Erbbedingtheit

erbbiologisch

e. rein

Erbdiagnose

Erbgang

erbgesund (sein)

Erbgesundheit

Erbgutverschlechterung

erbkrank sein

Erbkrankheit

erblich belastet

e. b. sein

Erbprognoseziffer

IErb-Umweltproblem

Ernährungsschwierigkeiten

Erstbeschreibung (eines Syndroms)

Extensionsstellung - Versteifung der grossen Gelenke in $E$

Familiarität

Faunsgesicht talipes equinovarus; combined tip feet and inversion (of feet) ; association of tip feet with inversion of feet

genetically determined; determined by heredity ; genetic; hereditary ; inherited, caused by genetic factors

be due to recessive inheritance

hereditary cause (of a malformation); $h$. determination; $h$. causation (of a disease)

heredobiological; from the point of view of hereditary biology ; also : genetic

genetically pure

assessment of genetic risks; assessment of the genetic background

mode of inheritance ; course of inheritance; mechanism of (hereditary) transmission ; hereditary transmission

(be) free from hereditary disease ; (be) of healthy familial background

freedom from hereditary disease

racial degeneration ; deterioration of the hereditary constitution (of a population) ; impairment of the hereditary constitution (of a population)

have a hereditary disease

genetic disease or disorder; hereditary disease : heredopathy (-ia); heritable disorder; heritable condition; genetically conditioned disease ; inborn error of metabolism (Garrod, 1908) molecular disease (Pauling, 1964)

genetically tainted; genetical infirm; affected with a genetic disease; liable to manifest a genetic disease (at some time in the future); suffering from a genetic disease

carry a hereditary load ; carry a hereditary burden; be hereditarily burdened; be genetically burdened

risk figure (empirical)

nature-ys.-nurture question

feeding trouble; feeding difficulty (baby with Farber's syndrome, etc.); difficulty in nutrition (because of tongue and palate deformities, etc.)

original description (of a syndrome) (like Langdon Down's description of mongolian idiocy in 1866)

large joints (of the arms and legs) are ankylosed in extension; retention of the large joints in extended position

consanguinity ; familial occurrence (of a syndrome) ; kinship because of common ancestry ; familial predisposition; hereditary familial or heredofamilial (form of a) disease ; also : inbred group

gnome-like facies (as in Donohue's syndrome, i.e. a small hirsute face with nearly normal-sized ears, eyes, and nasal tip) ; old man face (in leprechaunism) 
Faust (eines Kindes mit Edwards-Syndrom)

fehlabgehend (Gefäss)

Fernrohrfinger

\section{Fetthals}

Fettverteilungstyp, weiblicher (bei Männern) gynecomastia

Finger - vergrösserter Abstand zwischen dem dritten und vierten $F$.

$F$., verwachsene

$F$., zylinderförmiger

Fingergliederverkürzung

Fischmaul

Fischwirbel (-bildung)

Flügelfell (am Nacken) ( $=$ an beiden Halsseiten)

Fontanelle, Persistenz der grossen

Frakturen schon vor bzw. bei der Geburt

Froschhals

Froschkind

Fruchtentwicklungsstörung

Funktionsstörung

Gabelrippe

Gallengangagenesie, kongenitale

Gangunsicherheit

Gargoylgesicht (-fratze)

Gefahr einer Unverträglichkeitsreaktion Gefährdung

Gefährdungszeit (characteristic) grasp (of a child with Edward's syndrome); tightly flexed fingers with a characteristic grasp in which the index finger overlaps the third, and the fifth overlaps the fourth

malposed (vessel)

telescope-like finger; telescope finger; opera-glass finger; doigt en lorgnette (a condition where the fingers may be elongated or shortened like a telescope or appear to be retracted into one another, in Marie-Léri syndrome and arthritis mutilans); also : opera-glass hand ; main en lorgnette

diffuse lipomatosis of the neck; adenolipomatosis of the neck (in Madelung's syndrome)

excessive development of the mammary glands (in men) :

trident hand

webbing of fingers; webbed fingers

cylindrical finger (that does not taper normally)

brachyphalangia (a genetic condition in which the phalanges of the fingers are abnormally short)

fish-like large mouth; (1) the carp-like mouth characteristic for Francescetti's syndrome (II) ; (2) the mouth seen in sardonic grin

vertèbre en diabolo (strangulation of the vertebral body between osteophytes pressing on the superior and inferior surface ; in Léri's syndr.)

pterygium colli; webbed neck; webbing of the neck

delayed closure of the fontanels ; persistent opening of the cranial fontanels; incompletely closed fontanels; open fontanels

fracture before or during birth (in Vrolik's syndrome)

shortened neck (in Klippel-Feil syndrome); brevicollis; homme sans cou

"frog baby" ; anencephalus ; anencephalic baby defective development of the embryo; defective embryonic development ; dysontogenesis

dysfunction ; abnormal function ; deranged $\mathrm{f}$.; impairment of $\mathbf{f}$; f functional disturbance(s) (of hands, feet, etc.)

bifid rib

familial intrahepatic biliary atresia

ataxia ; difficulty in walking; clumsy gait ; uncertain gait ; also : equilibrium disorder

gargoyle facies or face ; gargoyle-like facies ; Hurler-like facies (face with broad bridge of the nose, open mouth with protruding large tongue, and thickened lips)

incompatibility risk (in a $\mathbf{R h}$ situation)

risk ; hazard, jeopardy ; distress (of intrauterine fetus)

manifestation period (for a genetic disease) 
gefässähnliche Streifen am Augenhintergrund

Geldrollenagglutionation

Gelenkbeweglichkeit, eingeschränkte

Gelenkschlaffheit

Gelenkïberstreckbarkeit

Gennachbarschaft

geschlechtsabhängig

Geschlechtsbläschen

Geschlechtzugehörigkeit, unklare

Gesichtsverflachung

Gestaltungsfähigkeit

Gliawucherung (im Gehirn)

Gliederwerfen

Gliedmassendefekt, angeborener

Gliedmassenfehlbildung

\section{Griechennase}

gutmütig - ein g.-es Wesen besitzen (DownKinder)

gynäkotrop

Gynäkotropie

Gynäkotropie (10:1) angioid streaks of the retina (wide lines, reddish or greyish, around the optic disk, in GroenbladStrandberg syndrome)

rouleaux formation (of erythrocytes); reversible pseudoagglutination (of red cells in vitro) ; clumping tendency of erythrocytes simulating true agglutination

limited or restricted mobility of joint(s); stiffness of joints; tight joints ; stiff joints (e.g. inability to flex the fingers completely or to make a fist); slight limitation of joint motion ; limited joint motion ; limitation of extension of joints (in Pyle's syndrome)

joint laxity ; articular hypermobility, loose joints hyperextensibility of joints; hyperflexibility of joints ; joint hypermobility ; hypermobile and loose joints; joints are loose and hypermobile (as finding)

gene propinquity (-ies) (used almost exclusively in the singular in German, and in the plural in English !)

sex-controlled (Goldschmidt, 1920)

sex vesicle (Sachs, 1954) the human $X$ and $Y$ chromosomes, as a pair, condense into a darkstaining, heteropycnotic body called the s.v. in which they are assumed to be paired by a small terminal region of homology during the meiotic prophase)

ambiguous sex

sunken cheek bones; flattening of malar or facial bones (in Treacher Collins; syndrome)

organizing ability (in embryology)

proliferation of glial cells; increased number of glial cells (throughout the brain)

jactation of limbs; rhythmic tossing about of the limbs

teratic malformation of limb(s) ; congenital defect of (one or more) extremities

malformation of a limb or limbs; congenital limb abnormalities; congenital abnormality with missing or foreshortened extremities ; congenital abnormality caused by disturbance at the time of limb anlage development

Grecian nose (straight nose coming off sharply from the forehead, in Edwards' syndrome)

be good-natured ; be sweet-tempered ; be wellnatured

limited to female (hereditary disease); prevalent in female; predominant in females; also : affecting females more frequently than males gynecotropism (cf. also under Androtropie)

females affected ten times more than males; occurring almost exclusively in females (like Bloch-Sulzberger syndrome); predominant in female (10:1) 


\section{Haarmensch \\ Habitus - einen weiblichen/ männlichen $\boldsymbol{H}$. haben \\ Haifischmaul}

Halsfistel

Haltungsanomalie

Harn - eigenartiger Geruch des H.-es nach verbranntem Zucker oder nach MaggiSuppenwürze

H. - nach Mäusen bzw. Mäusekot riechender $H$.

Harnstauung

Hasenauge

Hauptsymptom

Hautleistenmuster

hautiuberwachsen (Augen)

Hemmungsmissbildung

Herzanlage

Hiob-Syndrom

Hochwuchs

holandrisch

hologyn

Holzschuhherz

Hornhauttrübung

Hummerklaue (-schere) individual suffering from (congenital) hypertrichosis lanuginosa; individual with congenital hypertrichosis

appear to be female/male; have a female or feminine/male or masculine appearance or body contour

shark mouth; shark-like mouth; mouth with thin lips and downturned corners (in Sliver's syndr.); downturning of mouth

branchial sinus; branchial fistual (in FourmanFourman and Rowley's syndromes)

posture defect ; postural abnormality ; abnormal posturing ; faulty posture (as finding)

maple syrup odor of the urine

urine with a musty odor; urine with a mousey odor (in Fölling's syndrome)

accumulation of urine (in the convoluted tubules, in congenital cystic kidney)

hare's eye ; lagophthalmia ; poor eyelid closure [as symptom in Möbius's syndrome (II)]

cardinal symptom; principal symptome or feature; main feature; major diagnostic feature (of a syndrome) principal manifestation;

pattern of epidermal ridges ; epidermal pattern on the hands and fingers; dermatoglyphics

skin passing continuously (from forehead onto cheek over a rudimentary eye)

developmental defect; embryonal d. d. ; defect due to an arrest of embryonic development

pericardial bulge (on each side of the midline in the cephalic part, in human embryo at day 22-23); bulging pericardial area ; heart bulge (approx. day 25)

Job's syndrome; Job's dermatitis syndrome ; chronic granulomatous disease variant (named after Job because this syndrome involves feelings of depression, guilt, and rejection from relatives and friends)

increased stature; elevated stature; tall stature; high stature; tall and slender build; elongated body

holandric; holandrous; inherited only in the male line from father to son (generation after generation); appearing in men only

hologynic; hologynous; inherited only in the female line from mother to daughter (generation after generation); appearing only in females

sabot heart; cceur en sabot; wooden-shoe heart (in the tetralogy of Fallot, etc.)

cf. above in the text

clawhand ; lobster-claw hand; lobster-claw deformity; bidactyly (if only $1^{\text {st }}$ and $5^{\text {th }}$ digits are present) 
Hundemensch

Igelfuss

Indexgruppe

Infektanfälligkeit

Inzuchtkind

Irisflecken (weissliche)

Keilwirbel

Kieferkerbe

Kleinwuchs

Knabenwendigkeit $=$ Androtropie Krokodilschuppenbaby

Lidwinkel - vermehrter Abstand der inneren $L$.

Linsenschlottern Mädchenwendigkeit = Gynäkotropie

M'iauen

\section{M'ilchleiste}

Mropsgesicht

Nagelabstossung

Oberflächensensibilität

Ölfleck

Olympierstirn

Papageienschnabelnase

Pausbackengesicht

Pelzigkeitsgefuihl

Pillendrehen individual suffering from congenital hypertrichosis lanuginosa with gingival hyperplasia

presence of pointed osteophytes on the dorsal side of the tarsus (chiefly in gout)

typical average group

susceptibility to (respiratory) infections; history of (r.) i. ; frequent (r.) i. ; repeated (r) i.

child of inbreeding; usually child of a cousin marriage ; also child of father-daughter incest ; child of brother-sister incest ; child of a nieceuncle marriage

small whitish (or very light yellow) speckles in the iris ; iris with small whitish speckles;

Brushfield's spots (in Down's syndrome)

wedgelike deformity of the (lumbar and thoracic) vertebrae

(midline) notch of the jaw ; pseudocleft of the jaw

dwarfism; nanism; stunted growth ; short stature; shortness of stature; growth retardation; small for date (infant) (cf. Minderwuchs)

alligator baby ; infant suffering from either ichthyosis congenita or ichthyosis sauroderma ; baby suffering from hyperkeratosis with armorplate-like scales

lateral displacement of the medial canthi (with normal interpupillary distance!) (in Waardenburg's syndrome)

tremolous lens (and iris) due to subluxation of the lens [in Marfan's syndrome (I)]

cat cry ; cri du chat ; mewing cry ; a peculiar cry resembling that of a suffering kitten; strange high $=$ pitched plaintive cry (voiced by infants) reminescent of the cry of a cat

mammary line ; mammary ridge (in embryonic development); milk ridge ; mammary fold bulldog face [in Parrot's disease (II]

nail shedding (in Judassohn-Lewandowski syndr.)

cf. above in the text

brownish-gree spot in the nail in subungueal psoriasis vulgaris

olympian forehead (abnormally high and vaulted forehead)

(birdlike facies with) prominent beaked nose ; parrot-beaked nose; beak-shaped nose (in Crouzon's syndrome)

cherubic face; face marked by protuberance of the cheeks and jaws (and upturned eyes); the characteristic face of cherubism (= Jones' disease) : face marked by fullness of the cheeks and jaws

numbness (in hands and feet); furry and numb sensation; unpleasant furry paresthesia of the extremities

pill-rolling movements or motion of the fingers and hands); the slow movements with 


\section{Radiergummiphänomen}

Risikoschwangerschaft

Robbenmensch

rückverfolgen

Sandalenlücke

Schnauzengesicht

Schneidersitz

Schulterblatthochstand, angeborener

Stachelschweinmensch

Stirnhöcker

Stirnlocke, weisse

Streichholzwade

Tiefensensibilität

Trommelschlegelfinger

Trommelschlegelzehen

Überbehaarung

Uhrglasnägel

Unvertäglichkeitsbürde

Verwachsung, fibröse

$V$., ossäre

Vogelbein

Vogelgesicht (= Vogelkopfgesicht)

Vogelgesichtigkeit involuntary tremor performed by the fingers of a subject suffering from Parkinson's syndrome scaling or peeling of the skin produced by mild rubbing

high-risk pregnancy

an individual with phocomelia; phocomelus trace (an abnormality) back

increased distance between the first and second toes (in Seckel's syndrome)

facies with a wide mouth, protruding maxilla, and short nose (in Morquio's syndrome) ; broadmouthed facies

tailor position; tailor positioning when sitting (in Fölling children)

Sprengel's deformity (as congenital condition); congenital elevation of the shoulder ; congenital winging of the scapula

porcupine man ; individual suffering from ichthyosis hystrix gravior

frontal bossing; frontal boss(es); boss(es) of the frontal (or partial or biparietal) region(s)

white forelock (in certain forms of metabolic insufficiency and as sign of circumscribed albinism)

atrophy or dystropy of the muscles of the calf (as in pes equinovarus congenitus)

deep sensibility ; muscular s. ; mesoblastic s. ; myesthesia ; myoesthesia; sensations derived from the muscles, joints, tendons and deep layers of the skin

digital clubbing ; clubbing of the fingers; clubbing of the distal phalanges of the fingers; digiti hippocratici; hippocratic fingers; clubbed digits

clubbing of the toes; clubbing of the distal phalanges of the toes

excessive hairiness ; hypertrichosis ; marked hirsutism ; extreme h.; excessive body hair [in (Cornelia) de Lange's syndrome (I)]

hippocratic nails; ungues hippocratici ; coarse, curved nails capping clubbed fingers; nails are watch-crystal-like (finding)

incompatibility load (usually between mother and unborn child)

webbing (of fingers, etc.)

bony fusion (of fingers) ; ankylosis

dropfoot; stork leg; foot drop (with sloping gait) ; (the legs typical for Charcot-Marie and Berlin's syndromes)

bird-like facies ; bird-like facial structure ; bird face; brachygnathic face (with underdeveloped mandible)

bird-like facies (thin beaked nose, small mouth, dental abnormalities, microphthalmia, etc.) ; mandibulo-oculo-facial dysmorphia or dyscephaly 
Wachstropfen - wie W. an einer Kerze

Watteschädel

Zahn, abgekauter

Zahnradphänomen

Ziehengliederverkürzung

zelleigener Genotyp

Zungenlappung

Zwergwuchs

Zwillinge, eineiige

Z., zweieige

Zwischenvergleich (bei Populationen) resembling melted wax flowing down the side of a candle [the hyperostotic protrusions on the long bones, in Léri's syndrome (I)]

the soft, decalcified skull of an individual suffering from Paget's disease

crownless tooth (due to wearing down to the gum level, in Capdepont's syndrome)

cogwheel rigidity (a type of rigidity seen in Parkinson's syndrome, with movements active or passive - interrupted by cogwheel jerks

pedibrachyphalangia (a genetic condition in which the pediphalanges are abnormally short)

the cell's own genotype

lobulated tongue; bifid tongue; cleft of tongue with two or more lobules

dwarfism ; nanism ; failure to grow ; short individual; dwarfed (as finding)

identical twins ; monozygotic t. ; enzygotic t. ; monochorial t. ; monovular t. ; uniovular t. ; MT

fraternal twins; dyzygotic t.; heterologous t. ; dichorial t.; diovular t. ; unidentical t. ; DT inter-population comparison 